\title{
Cognitive Style and Learning Strategies as Factors which Affect Academic Achievement of Brazilian University Students
}

\author{
Estilo Cognitivo e Estratégias de Aprendizagem em Estudantes Universitários \\ Brasileiros: Repercussões no Rendimento Acadêmico
}

\author{
Carolina Tinajero*, ${ }^{*}$, Sônia Maria $\operatorname{Lemos}^{b}$, Margarete Araújo $^{b}$, \\ M. José Ferraces ${ }^{a} \&$ M. Fernanda Páramo ${ }^{a}$ \\ ${ }^{a}$ Universidad de Santiago de Compostela, Santiago de Compostela, España \\ $\&{ }^{b}$ Universidade Luterana do Brasil, Canoas, Brasil
}

\begin{abstract}
In the present study, the influence of the cognitive style called field dependence-independence on academic achievement of Brazilian university students was explored as well as the mediating effect of learning strategies on that influence. Learning strategies of 313 first-year university students (189 women and 124 men; $M$ age $=20.86, S D=3.86)$ from different fields, with upper, medium and lower scores on field dependence-independence were assessed on a self-report questionnaire and their overall academic marks in the first year were registered. Results of a regression analysis showed that cognitive style and learning strategies significantly contributed to academic achievement. A path analysis revealed that planning strategies mediated the influence of cognitive style on achievement.

Keywords: Field dependence-independence, cognitive style, learning strategies, self-regulated learning, academic achievement.

Resumo

No presente estudo, a influência do estilo cognitivo dependência-independência de campo no rendimento acadêmico de estudantes universitários brasileiros foi explorada, bem como o efeito mediador das estratégias de aprendizagem nesta influência. As estratégias de aprendizagem de 313 estudantes universitários de primeiro curso ( 189 mulheres e 124 homens, idade $M=20,86, D P=3,86$ ) a partir de diferentes domínios, com pontuações elevadas, intermediárias e baixas em dependência-independência de campo, foram avaliadas em um auto questionário e as suas médias globais de rendimento acadêmico no primeiro ano foram registradas. Resultados de uma análise de regressão mostraram que o estilo cognitivo e as estratégias de aprendizagem contribuem significativamente para o sucesso acadêmico. Uma path analysis revelou que as estratégias de planejamento mediam a influência do estilo cognitivo na sua realização.

Palavras-chave: Dependência-independência de campo, estilo cognitivo, estratégias de aprendizagem, aprendizagem auto regulada, desempenho acadêmico.
\end{abstract}

Cognitive styles are defined as consistent patterns of functioning which are mainly present in perceptual and intellectual activity (Rayner \& Riding 1997; Riding, 1997). They establish a qualitative approach to behavior, in contrast to the dominant quantitative approach outlined by aptitudinal dimensions (Messick, 1994). Therefore, going beyond the labels for personal performance, they describe tendencies of confronting different situations, guiding the interpretation of superiority or disadvantage in certain circumstances and suggesting ways of intervention.

\footnotetext{
"Address: Departamento de Psicología Evolutiva y de la Educación, Universidad de Santiago de Compostela, Facultad de Psicología, Rúa Xosé María Suárez Núñez, $\mathrm{s} / \mathrm{n}$, Campus Vida, Santiago de Compostela, España 15782. E-mail: carolina.tinajero@usc.es.
}

Field dependence-independence is considered one of the most heuristic cognitive style constructs (Messick, 1996; Price, 2004; Sternberg, Grigorenko, \& Zahn, 2008; Sternberg \& Williams, 2002) and has been shown consistently to determine academic professional trajectory (Guisande, Páramo, Soares, \& Almeida, 2007a), the way teachers teach (Evans, 2004) and the type of interaction between teacher and student (Saracho, 2000). Moreover, depending on the proximity to the extremes of the dimension, individuals show diverse ways of information processing which seem to modulate their academic achievement. In fact, we can assert that field-dependence places students at risk for poor school outcomes, whereas field-independence favors a student's success (Cano, 2006; Danili \& Reid, 2006; Garton, Ball, \& Dyer, 2002; Hederich, 2004; Tinajero \& Páramo, 1997, 1998; Zhang 
\& Sternberg, 2005). The same effects have been observed for Brazilian accounting students (Oliveira, Oliveira, \& Souza, 2009). The influence of cognitive style on achievement of students from other university disciplines and from lower educational levels remains unexplored in Brazilian context.

The research on information processing and its relation to cognitive style, has revealed some trends that could explain differences in achievement. Field-independent individuals, who are characterized by confidence in internal references and in their own criteria, tend to assume an analytical approach towards information that allows them to break it down into its component parts and restructure it according to their needs. This appears to enable spontaneous multiple operations using the information, such as classifying it or generating related inferences and hypotheses. As a consequence, individuals with a field-independent style are considered active processors (Guisande, Páramo, Tinajero, \& Almeida, 2007b; Rozencwajg, 1991; Tsakanikos, 2006).

In contrast, individuals with a field-dependent style are more sensitive to external clues and thus tend to take information exactly as it is presented to them, and in what appears to be an effort to capture the structure of this information, they normally attend to its global aspects. This tendency is an obstruction to intellectual tasks that demand focus on isolated elements within a perceptive or symbolic whole - as in the perceptual disembedding tasks used as measures of cognitive style - or in those that involve restructuring of information. Moreover, the global approach favors a passive, expectant attitude in the face of intellectual tasks (Baker \& Dwyer, 2005; S. Y. Chen, Magoulas, \& Macredie, 2004; Handal \& Herrington, 2004).

Apart from these general descriptions, we need data on the specific performance of individuals in an educational context as related to field-dependent and fieldindependent cognitive styles. They would enable us to design training programs for subjects with different cognitive styles and to adjust the instructional design for them. A way of approaching this issue would be exploring the relationship between field dependence-independence and learning strategies, which are regarded as essential for academic achievement; their training is considered one of the main means of reducing academic failure (Boruchovitch, 1999; Martín, García, Torbay, \& Rodríguez, 2008; Pintrich \& De Groot, 1990; Pocinho, 2010; Vrugt \& Oort, 2008).

For the moment, the available data on the relationship of cognitive style with learning strategies are mainly derived from research focusing on other aspects, like academic achievement, cognitive processing, or adaptation of instructional methods and materials. Nevertheless, the findings allow advancement of specific hypotheses. In order to provide an overview of the current state of empirical knowledge, we'll take as references the classifications made by Dansereu (1985), Kirby (1984) and
Weinstein and Mayer (1986), given the support they have received and their coherence with the latest models of academic learning. Basing on their similarities, we may distinguish three types of learning strategies: support or resources management strategies, cognitive strategies or micro-strategies and meta-cognitive strategies or macro-strategies.

Support or resources management strategies are defined as those applied to both personal and contextual conditions of learning tasks and modulating pupils' levels of engagement. These strategies include motivational and volitional control, environmental structuring, and helpseeking activities (Dansereu, 1985; Kirby, 1984; Pintrich, Smith, García, \& McKeachie, 1991; Vermunt, 1996; Weinstein \& Mayer, 1986; Zimmerman \& Martinez-Pons, 1990). Studies on adaptive teaching have brought out motivational differences due to cognitive style such as differential effects of competitive situations, incentives and feedback on learning (Bolocofsky, 1980; Ennis, 1991). Nevertheless, for the moment, data are lacking about the relation of field-dependence with the use of support strategies as those aforementioned.

Cognitive strategies or micro-strategies are used to encode, comprehend, and retrieve data to attain specific learning goals (Dansereu, 1985; Kirby, 1984; Pintrich et al., 1991; Vermunt, 1996; Weinstein \& Mayer, 1986; Zimmerman \& Martinez-Pons, 1990). They encompass reproduction, selection, elaboration, and organization activities. Some studies have revealed that field-dependent students are more prone to use reproduction strategies compared to others, whether the learning material is simple, such as a word list, or complex, such as a digital course (Frank \& Keene, 1993; Liu \& Reed, 1994); that is, they tend to simply repeat the information orally or mentally. Currently, neither the relation of the cognitive style with use of this strategy, nor the consequences for retrieval, have yet been explored.

Using selection strategies, students separate relevant from secondary, redundant, or confusing information, to facilitate a deeper processing of the former; related actions comprise note-taking and summarizing. When students with field-dependent and field-independent cognitive styles are compared in relation to note-taking skills on written texts, the groups produce similarly precise and organized notes (Annis, 1979; Kiewra \& Frank, 1986; Stern \& Hassanein, 1992) and, in fact, the retrieval by both groups is equally enhanced by note-taking (Rickards, Fajen, Sullivan, \& Gillespie, 1997). However, when notes must be taken from oral speech, students with fieldindependent style used fewer words than those with fielddependent style, suggesting that the former lean on previous knowledge to a greater extent (Frank, 1984). This idea fits Fehrenbach's (1994) data about summaries of written texts, which suggest that students with field-independent style are not only more prone to spontaneously summaries school materials, but they are more accurate when invited to use this strategy and, as a 
Tinajero, C., Lemos, S. M., Araújo, M., Ferraces, M. J. \& Páramo, M. F. (2012). Cognitive Style and Learning Strategies as Factors which Affect Academic Achievement of Brazilian University Students.

consequence, they remember more oral information.

Students use elaboration strategies when they add meaning to the learning material by making symbolic constructions. Simple and complex elaboration are commonly distinguished, the first consisting of forming an integrated whole (for example an image or a sentence) associating pieces of the information to be retained (as items on a list). On the other hand, complex elaboration consists of relating new material to previous knowledge logically or by analogy (Dansereu, 1985; Kirby, 1984; Pintrich et al., 1991; Vermunt, 1996; Weinstein \& Mayer, 1986; Zimmerman \& Martinez-Pons, 1990). Studies on simple elaboration strategies, such as visual imagery or verbal association, suggest that field-independent learners are more prone to autonomously use this type of process (Corson, Verrier \& Bucic, 2009; James \& Moore, 1991; Tsakanikos, 2006), and when instructions to perform them are given, retention improves to a greater extent among those with field-independent style in the case of imagery strategies (Carrier, Joseph, Key, \& LaCroix, 1983; Pierce, 1980).

Data about complex elaboration are more clarifying about the learning process. Students with field-dependent style obtain better scores on analogies tests when pairs of related words are given (Johnson \& Rosano, 1993). Those with field-independent style, however, show greater ease at generating analogous concepts by themselves, based on their prior knowledge (Antonietti \& Gioletta, 1994; Johnson \& Rosano, 1993); in fact, they seem more prone to use, transfer, and modify their own prior concepts (AlJubaili, 2002; Cochran \& Davis, 1987; Kang, Scharmann, Noh, \& Koh, 2005; Spiro \& Tirre, 1980). Perhaps this tendency is also involved in the way students with different cognitive styles use the self-questioning strategy. Students with field-independent style are more specific when generating questions about texts to be learned, although this characteristic is not associated with better results on recall (Adejumo, 1983).

Organizational strategies are the identification or assignment of structure to new material, for example, by outlining, clustering, concept mapping or sketching a network or diagram of the important ideas (Dansereu, 1985; Kirby, 1984; Pintrich et al., 1991; Vermunt, 1996; Weinstein \& Mayer, 1986; Zimmerman \& Martinez-Pons, 1990). Students with field-independent style have shown a greater tendency to use this type of strategy: specifically, for a clustering strategy, either applied to drawings or to texts (Coward \& Lange, 1979; Frank \& Keene, 1993) and for networking or making diagrams for memorizing a text (Emmett, Clifford, \& Gwyer, 2003; Fehrenbach, 1994; Kahtz, 1999). Nevertheless, this wider structuring tendency does not lead to better retrieval, except in the case of graphical data recall (Coward \& Lange, 1979; Lipsky, 1989; O’Connor \& Blowers, 1980).

Finally, some authors have shown interest in metacognitive strategies or macrostrategies which include activities that help students in their learning planning, monitoring, and evaluation. An association of fielddependence with the desire to plan and monitor one's own learning has been registered, as well as a greater efficiency of these processes (Abraham, 1983; Boutin \& Chinien, 1992; Liu \& Reed, 1994). In fact, students with fieldindependent style maintain a greater consciousness of their learning experiences and their personal role in them (Boutin \& Chinien, 1992).

The present work aims to provide data on the influence of cognitive style academic achievement in Brazilian student population and to evaluate the possible predictive value of the cognitive style dimensions and learning strategies on academic achievement; besides proposing an explanatory model of achievement taking into account the variables mentioned above.

\section{Method}

\section{Participants}

The sample selected in this study consisted of 313 first year university students aged between 17 and $30(M=$ $20.86, S D=3.86$ ). They attended courses in: Agriculture, Administration, Architecture, Biology, Accounting, Law, Environmental Engineering, Mechanical Engineering, Electrical Engineering, Chemical Engineering, Civil Engineering, Nursing, Physiotherapy, Psychology, Chemistry and Information Systems. They were students at Manaus University Center/AM and from the Institute of University Education in Itumbiara/GO.

\section{Instruments}

Field Dependence-independence. The Group Embedded Figures Test (Witkin, Oltman, Raskin, \& Karp, 1971) was administered after been translated into Portuguese. The test consists of a booklet containing 25 complex geometric designs, sorted into three sections. The first section consists of seven different designs as practice for the actual test, which consists of two sections, each one comprising nine complex figures. The last page of the booklet contains eight simple figures. The task consists of finding and marking the indicated simple designs within the complex designs. The participant is given a maximum of five minutes to complete each of the two last sections. The test score is the total number of figures correctly located. The alpha coefficient of the Group Embedded Figures Test has been reported as .82 (Witkin et al., 1971). Kepner and Neimark (1984) reported test-retest reliability coefficients over three different intervals as between. 78 and .92. Additionally, the Group Embedded Figures Test exhibited criterion validity by correlations with the Embedded Figures Test and the Rod and Frame Test (Witkin et al., 1971).

Academic Achievement. Achievement was measured by the mean marks (computed on a scale from 0 to 10) obtained by the students during the first semester.

Learning Strategies. Strategies were assessed using the Learning and Study Inventory (LSSI; Weinstein, 1987), 
translated into Portuguese by Figueira and adapted by Bartalo (2006). This questionnaire is based on Weinstein and Mayer (1986)'s model and has reached great diffusion. It consists of 77 questions distributed into the following grouping categories: (a) Anxiety, which covers concern about school and academic achievement - with a minimum score of 8 and maximum of 40; (b) Attitude, which relates to the values that students attribute to school and to the interest for academic success in order to obtain good jobs - with a minimum score of 7 and maximum of 35; (c) Concentration, which seeks to assess the ability that the student has to direct his/her attention and keep it in academic activities - with a minimum score of 8 and maximum of 40; (d) Motivation, aims to evaluate motivational and volitional control strategies, that is, the self-discipline and strength to work with determination, and to evaluate its self-disposition to meet academic requirements - with a minimum score of 9 and up to 45 ; (e) Study Auxiliaries, which seeks to examine the level of use of organization strategies - with a minimum score of 8 and maximum of 40; (f) Time organization, which seeks to assess the time management principles application to academic situations; (g) Information Processing, which aims at evaluating the use of complex development strategies - with a minimum score of 8 and maximum of 40; (h) Selection of Main Ideas, which includes the evaluation of the ability to identify what information is of greater relevance in a text - with a minimum score of 6 and maximum of 30; (i) Verification, which has the purpose of planning the study and assessment tests with minimum score of 8 and maximum of 40; (j) Selfchecking, which aims to evaluate the ability to revise the material to be learned as well as to monitor the understanding of this material - with a minimum score of 8 and maximum of 40 .

Bartalo (2006) reports internal consistency rates between .76 and .78 for the various subscales, and correlation coefficients between subscales of .12 and .62 . In the present study sample internal consistency values of $\alpha=.90$ for the scale and between .65 and .77 for subscales were obtained.

\section{Procedure}

The research project had been submitted to the Ethics Committee from Lutheran University Center of Manaus and the Lutheran Institute of University Education in Itumbiara respectively and were approved under protocol numbers $017 / 2010$ and $050 / 2010$.

After being told by teachers that participating in the study would not involve any risk, and that their identities would be preserved, students signed a Free and Clear Consent Form (FCCF). All tests were administered in onehour sessions, following the same order for all participants. The Group Embedded Figures Test was applied first, to prevent an effect of fatigue produced in the execution of the LASSI, since the latter takes about 40 minutes to complete.

\section{Data Analysis and Results}

The first objective of this study was to provide data on the influence of cognitive style on academic achievement in Brazilian college students. The sample was divided into three groups (thirds), according to scores on the Group Embedded Figures Test. The lower third of the distribution, consisting of those individuals whose scores were between 0 and 3 ( 90 students) was considered the field-dependent group. At the top, were located fieldindependent students, with scores between 9 and 18 (86 individuals). Finally, an intermediate group was distinguished which was conformed by 137 students with scores between 4 and 8 .

An Analysis of Variance (ANOVA) was used to compare mean marks of field-dependent, field-independent and intermediate students; significant differences were obtained $\left(F_{(2,309)}=8.77, p=.0001\right)$. Post hoc contrasts showed significant differences between field-independent and field-dependent groups (MI - Md $=.640, p=.002$ ) and between the field-dependent and intermediate groups (MD - MIN = -.630, $p=.001)$. However, no significant differences were observed between the field-independent and intermediate groups. According to these data, field-dependent students obtained poorer academic achievement than the other two groups examined.

In order to analyze the predictive value of both cognitive style and learning strategies in academic achievement, a linear regression analysis was conducted, using the successive steps method, taking cognitive style and scores on each LASSI subscale as independent variables and the academic achievement as dependent variable. Moreover, in order to check whether the sample of the present study contained atypical values, Cook's statistic was applied and influence values were calculated resulting in a maximum score of .01 (it must be less than 1) and an influence point of .050 was obtained (it mustn't exceed 5); we may then assume that the sample doesn't contain atypical values. The results of this analysis are shown in Table 1.

Table 1

Results of Linear Regression Analysis that Predicts the Academic Achievement

\begin{tabular}{lccc}
\hline & Model 1 & Model 2 & Model 3 \\
\hline Verification & $.416^{*}$ & $.342^{*}$ & $.317^{*}$ \\
Motivation & & $.176^{*}$ & $.178^{*}$ \\
GEFT & & & $.140^{*}$ \\
$F$ & $60.74^{*}$ & 34.49 & 25.87 \\
$G . L$ & 311 & 311 & 311 \\
$R^{2}$ & .173 & .198 & .217 \\
$\Delta R^{2}$ & .173 & .026 & .019 \\
\hline
\end{tabular}

$* p<.0001$.

According to the analysis results, three variables significantly affect the academic achievement (cognitive 
style, planning strategies, and motivational and volitional control strategies), accounting for $21 \%$ of the variance. Planning strategies showed the greater effect. Basing on these results, we proposed an explanatory model for achievement, considering cognitive style, volitional and motivational control strategies, and planning strategies. A structural equations analysis (path-analysis) was applied using the AMOS program, in order to prove its fitness. Standardized estimates are shown in Figure 1, as well as variance explained by the model and regression weights of independent variables. As noted, verification strategies $(\beta=.31)$ have a direct and positive influence, followed by the GEFT variable $(\beta=.15)$, which also acts indirectly modulated by the Verification strategies $(.14 \mathrm{x}$ $.31=.043)$. An overall effect of $.15+.043=.019$ was obtained.

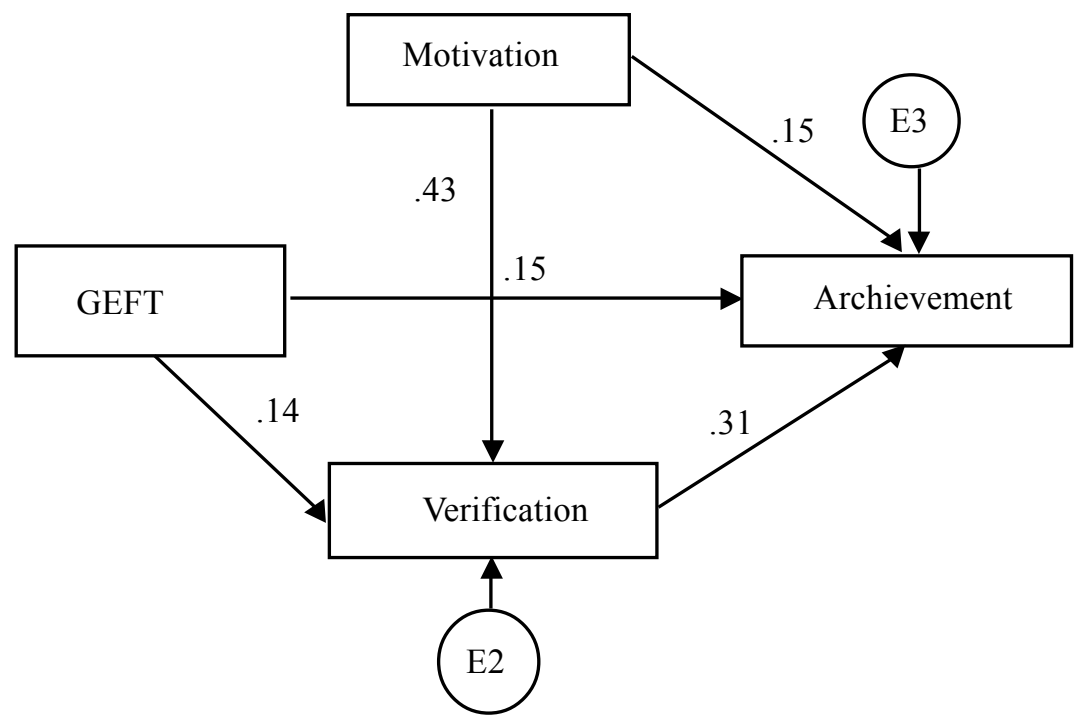

Figure 1. Standardized estimates corresponding to the explanatory model of academic achievement.

The most commonly used indicators according to Bentler (1990) are: $\chi^{2} / g l$ (its value must be less than 2; in the present analysis a value of 1.24 was obtained), GFI (Goodness of Fit Index: a value close to 1 indicates a good adjustment, a value of .99 was obtained), CFI (Comparative Fit index: a value close to 1 indicates a good adjustment, a value of .98 was obtained) and RMSEA (an index related to degrees of freedom: a value less than .05 indicates a good adjustment, a value of .028 was obtained in the present study).

Finally the possible mediating role of planning strategies in the relationship of cognitive style with academic achievement was examined. A linear regression analysis was performed in three steps (Baron \& Kenny, 1986 see Figure 2). The first one made possible to confirm the relationship between the predicting variable (cognitive style) and the dependent one (the academic achievement $-\beta=.058, p=.0001)$. The second one shows a cognitive style significant influence on planning strategies (mediator variable $-\beta=.267, p=.003)$. In the third step, the influence of learning strategies on academic achievement was shown $(\beta=.073, p=.0001)$. The Sobel test (1982) confirmed the significant effect of the mediation proposed from the explanatory model $(Z=3.08, p=.001)$ and it allowed to specify that the contribution of cognitive style, moderated by the strategies, was $8 \%$ of the total variance.

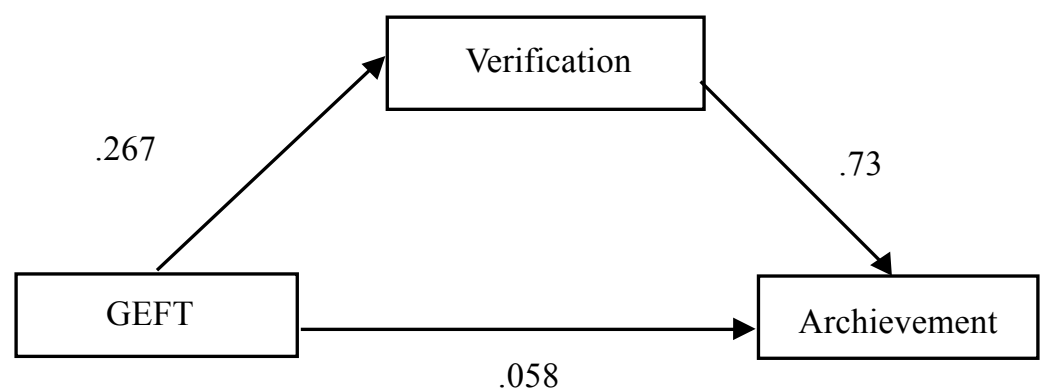

Figure 2. Linear regression analysis performed for the scores on planning strategies, cognitive style and academic achievement. 


\section{Discussion}

The influence of cognitive style on academic achievement was analyzed both with reference to specific subjects, as well as to overall achievement. The data available indicate that field-dependent students consistently obtain worse results than their field-independent classmates. This trend has been observed in different educational levels and has been confirmed with samples from several culture origins (Cano, 2006; Danili \& Reid, 2006; Garton et al., 2002; Hederich, 2004; Oliveira et al., 2009; Tinajero \& Páramo, 1997, 1998; Zhang \& Sternberg, 2005). However, we scarcely have data for Brazilian students. In accordance with previous investigations, results from the present study show that Brazilian college students with high scores on field-dependence obtain lower achievement than their peers with lower and intermediate scores. These results encourage the examination of the processes which determine the influence of cognitive style on academic achievement and places a substantial part of student population at risk for academic failure.

As noted in the introduction, investigations have been carried out on how field-dependent and field-independent individuals process information (Baker \& Dwyer, 2005; S. Y. Chen et al., 2004; Guisande et al., 2007b; Handal \& Herrington, 2004; Rozencwajg, 1991; Tsakanikos, 2006). However, there is a considerable gap between these investigations and those exploring the relationship between field dependence-independence and academic achievement. Studies from the information processing point of view do not usually consider the implications of their results for education. In the latter type of study, there are generally no attempts to elucidate the specific processes that originate the observed differences in achievement. Establishing links between both types of cognitive style manifestations would serve as a good basis for the design of training programs for those strategies in which field-dependent students show disadvantage. A few attempts have been made in this line (see e.g. Ludwig \& Lachnit, 2004; Pennings, 1991; Rush \& Moore, 1991); although offering promising results, they have been limited to defining characteristics of field dependenceindependence (such as perceptive disembedding or analytical processing). Other measures with greater ecological validity remain unexplored.

The regression analysis performed in this study confirms the predictive power of field dependence-independence regarding academic achievement and reveals a significant contribution of scores on LASSI subscales of Motivation and Verification. Appropriate values of internal consistency were obtained for the study sample with this questionnaire.

Motivation subscale measures the students' ability to use motivational and volitional control strategies, while Verification covers items about planning studding and assessment tests. Both types of processes have consis- tently been shown to relate to academic achievement (Duckworth \& Seligman, 2008; Greene, Miller, Crowson, Duke, \& Akey, 2004; Nota, Soresi, \& Zimmerman, 2004).

In the present study, cognitive style and learning strategies jointly explained the $21 \%$ of variability on academic achievement, an appreciable percentage if we consider the multiplicity of situational and personal factors with potential influence, such as cognitive skills (Rohde \& Thompson, 2006) or family relationships (Fan \& M. Chen, 2001).

The processing mode and other personal characteristics related to cognitive style seem to be conditioning the interaction between the subjects' performance as learners and educational contextual factors, predictably conforming stable and consistent patterns of behavior associated with teaching-learning situation; they could be affective, cognitive and/or meta-cognitive types of patterns. Thus, we should pose the mediator or moderator role that motivational and volitional control strategies and planning strategies could exert on the influence of cognitive style on academic achievement.

In the present study, an explanatory model of academic achievement was suggested, taking into account cognitive style and learning strategies, and it was confirmed through path analysis, supporting that planning strategies could act as a moderating variable in the influence of cognitive style on academic achievement.

Planning is a meta-cognitive process present in selfregulated learning, which includes setting objectives and planning strategies, contents and contextual resources to be used during the academic task (Pintrich, 2002; Zimmerman, 2002). In a study by Liu and Reed (1994) with a university sample, field-independent students were found to impose a personal sequence on a computer course they had to follow, while their field dependent classmates followed the sequence established by the course. These results are consistent with those obtained in the present study, which has revealed that field independence favors the use of planning strategies.

In addition, the differential tendency to plan own learning, seems to reflect in academic achievement, acting as moderator on the influence of cognitive style on academic success or failure. It has been suggested that confidence in the internal references which characterizes field-independent subjects is more in harmony with meta-cognitive functioning: this could lead to an earlier and more efficient development of metacognitive abilities (Boutin \& Chinien, 1992; Davis \& Cochran, 1990; Liu \& Reed, 1994). If this is the case and considering the results of this study, specific training in planning strategies from primary education levels should be regarded as an immediate step in attending learning diversity due to cognitive style in academic contexts. Several proposals for teaching programs have been made with this aim, covering objectives formulation, procedures selection and self-competence beliefs, among others (see for example Núñez et al., 2011; Pressley \& Harris, 2006). 
Studies to explore the effectiveness of these proposals with field-dependent and field-independent students and its influence on academic achievement of these subjects are clearly needed. In the light of the results of this research, the mediating role of learning strategies in the influence of cognitive style on academic achievement should be also analyzed in pre-university educational levels.

A greater impact of cognitive style through learning strategies should be expected on less experienced students, as suggested by data available on the relationship between field dependence-independence and learning strategies that was summarized in the introduction and obtained mostly with students from primary education. If this was supported, a plausible line of progress in the investigation should be to determine whether cognitive style takes part on the manifestation of production deficiency and utilization deficiency which are both part of the normative process of strategies acquisition (Schneider, Hünnerkopf, \& Kron-Sperl, 2007).

\section{References}

Abraham, R. (1983). Relationship between use of the strategy of monitoring and cognitive style. Studies in Second Language Acquisition, 6, 17-32.

Adejumo, D. (1983). Effect of cognitive style on strategies for comprehension of prose. Perceptual and Motor Skills, 56, 859-863.

Al-Jubaili, A. Y. (2002). Science misconceptions and working memory capacity among Saudi adolescents: A neo-Piagetian investigation. Dissertation Abstracts International Section A: Humanities and Social Sciences, 63(6-A), 2126.

Annis, L. F. (1979). Effect of cognitive style and learning passage organization on study technique effectiveness. Journal of Educational Psychology, 71, 620-626.

Antonietti, A., \& Gioletta, M. (1994). Individual differences in analogical problem solving. Personality Individual Differences, 18, 611-619.

Baker, R. M., \& Dwyer, F. (2005). Effect of instructional strategies and individual differences: A meta-analytic assessment. International Journal of Instructional Media, 32, 69.

Baron, R. M., \& Kenny, D. A. (1986). The moderator-mediator variable distinction in social psychological research: Conceptual, strategic and statistical considerations. Journal of Personality an Social Psychology, 51, 1173-1182.

Bartalo, L. (2006). Mensuração de estratégias de estudo e de aprendizagem Leaming and Study Strategies inventory (LASSI). Adaptação e validação para o Brasil. (Tese de Doutorado não-publicada). Universidade Estadual Paulista Julio de Mesquita Filho, Marília, SP.

Bentler, P. M. (1990). Comparative fit indixes in structural models. Psychologycal Bulletin, 107, 238-246.

Bolocofsky, D. N. (1980). Motivational effects of classroom competition as a function of field dependence. The Journal of Educational Research, 73, 213-217.

Boruchovitch, E. (1999). Estratégias de aprendizagem e desempenho escolar: Considerações para a prática educacional. Psicologia: Reflexão e Crítica, 12, 361-76.
Boutin, F., \& Chinien, C. (1992). Synthesis of research on student selection criteria in formative evaluation. Educational Technology, 32, 28-31.

Cano, Y. (2006). Effect of field dependent-independent cognitive styles and cueing strategies on students recall and comprehension. (Unpublished doctoral dissertation). Virginia Politechnic Institute, Blacksburg, VA.

Carrier, C., Joseph, M. R., Key, C. L., \& LaCroix, P. (1983). Supplied visuals and imagery instructions in field independent and field dependent children's recall. Educational Communication and Technology Journal, 31, 153-160.

Chen, S. Y., Magoulas, G. D., \& Macredie, R. D. (2004). Cognitive styles and users' responses to structured information representation. International Journal of Digital Libraries, 4, 93-107.

Cochran, K. F., \& Davis, J. K. (1987). Individual differences in inference processes. Journal of Research in Personality, 21, 197-210

Corson, Y., Verrier, N., \& Bucic, A. (2009). False memories and individual variations: The role of Field DependenceIndependence. Personality and Individual Differences, 47, 8-11.

Coward, R. T., \& Lange, G. (1979). Recall and recallorganization behaviors of field dependent and fieldindependent children. Psychological Reports, 44, 191-197.

Danili, E., \& Reid, N. (2006). Cognitive factors that can potentially affect pupils' test performance. Chemistry Education Research and Practice, 7, 64-83.

Dansereu, D. F. (1985). Learning strategy research. In J. W. Segal, S. F. Chipman, \& R. Glaser (Eds.), Thinking and learning skills: Vol. 1 (pp. 209-239). Hillsdale, NJ: Erlbaum.

Davis, J. K., \& Cochran, K. F. (1990). An information processing view of field dependence-independence. In O. N. Saracho (Ed.), Cognitive style and early education (pp. 61-78). New York: Gordon and Breach Science.

Duckworth, A. L., \& Seligman, E. P. (2008). Self-discipline outdoes IQ in predicting academic performance of adolescents. Psychological Science, 16, 939-944.

Emmett, D., Clifford, B. R., \& Gwyer, P. (2003). An investigation of the interaction between cognitive style and context reinstatement on the memory performance of eyewitnesses. Personality and Individual Differences, 34 1495-1508.

Ennis, C. D. (1991). Instructional strategies to facilitate the learning of field-dependent children. The Journal of Educational Research, 73, 213-217.

Evans, C. (2004). Exploring the relationship between cognitive style and teaching style. Educational Psychology, 24, 509530.

Fan, X., \& Chen, M. (2001). Parental involvement and students' academic achievement: A meta-analysis. Educational Psychology Review, 13, 1-22.

Fehrenbach, C. R. (1994). Cognitive style of gifted and average readers. Roeper Review, 16, 290-292.

Frank, B. M. (1984). Effect of field independence-dependence and study technique on learning from a lecture. American Educational Research Journal, 21, 669-678.

Frank, B. M., \& Keene, D. (1993). The effect of learners' field independence, cognitive strategy instruction, and inherent word-list organization on free-recall memory and strategy use. Journal of Experimental Education, 62, 14-25. 
Garton, B. L., Ball, A. L., \& Dyer, J. E. (2002). The academic performance and retention of collage of agriculture students. Journal of Agricultural Education, 43, 46-56.

Greene, B. A., Miller, R. B., Crowson, H. M., Duke, B. L., \& Akey, K. L. (2004). Predicting high school students' cognitive engagement and achievement: Contributions of classroom perceptions and motivation. Contemporary Educational Psychology, 29, 462-482.

Guisande, A. M., Páramo, F., Soares, A. P., \& Almeida, L. S. (2007a). Field dependence-independence and career counseling: Directions for research. Perceptual and Motor Skills, 104, 654-662.

Guisande, M. A., Páramo, M. F., Tinajero, C., \& Almeida, L. S. (2007b). Field dependence-independence (FDI) cognitive style: An analysis of attentional functioning. Psychothema, 19, 572-577.

Handal, B., \& Herrington, A. (2004). On being dependent or independent in computer-based learning environments. $E$ Journal of Instructional Science and Technology, 7(2).

Hederich, C. (2004). Estilo cognitivo en la dimensión de dependencia-independencia de campo. Influencias culturales e implicaciones para la educación. (Unpublished doctoral dissertation). Universidad Autónoma de Barcelona, Spain.

James, J. W., \& Moore, D. M. (1991). Effects of imposed visuals and instructions to image in students of varying ages and cognitive styles. Journal of Mental Imagery, 15, 91-110.

Johnson, J., \& Rosano, T. (1993). Relation of cognitive style to metaphor interpretation and second language proficiency. Applied Psycholinguistics, 14, 159-175.

Kahtz, A. W. (1999). Field-dependent and field-independent conceptalisations of various instructional methods with an emphasis on CAI: A qualitative analysis. Educational Psychology, 19, 413-428.

Kang, S., Scharmann, L. C., Noh, T., \& Koh, H. (2005). The influence of students' cognitive and motivational variables in respect of cognitive conflict and conceptual change. International Journal of Science Education, 27, 1037-1058.

Kepner, M. D., \& Neimark, E. D. (1984). Test-retest reliability and differential patterns of score change on the group embedded figures test. Journal of Personality and Social Psychology, 46, 1405-1413.

Kiewra, K. A., \& Frank, B. (1986). Cognitive style: Effects of structure at acquisition and testing. Contemporary Educational Psychology, 11, 253-263.

Kirby, J. R. (1984). Cognitive strategies and educational performance. New York: Academic Press.

Lipsky, S. A. (1989). Effect of field independence/dependence on two textbook notetaking techniques. (ERIC Document Reproduction Service No. ED 311983).

Liu, M., \& Reed, W. M. (1994). The relationship between the learning strategies and learning styles in a hypermedia environment. Computers in Human Behavior, 10, 419-434.

Ludwig, I., \& Lachnit, H. (2004). Effects of practice and transfer in the detection of embedded figures. Psychological Research, 68, 277-288.

Martín, L. A., García, Á., Torbay, A., \& Rodríguez, T. (2008). Estrategias de aprendizaje y rendimiento académico en estudiantes universitarios. International Journal of Psychology and Psychological Therapy, 8, 401-412.

Messick, S. (1994). The matter of style: Manifestations of personality in cognition, learning, and teaching. Educational Psychologist, 29, 121-136.
Messick, S. (1996). Bridging cognition and personality in education: The role of style in performance and development. European Journal of Personality, 10, 353-376.

Nota, L., Soresi, S., \& Zimmerman, B. J. (2004). Self-regulation and academic achievement and resilience: A longitudinal study. International Journal of Educational Research, 41, 198-215.

Núñez, J. C., Cerezo, R., Bernardo, A., Rosário, P., Valle, A., Fernández, E., et al. (2011). Implementation of training programs in self-regulated learning strategies in Moodle format: Results of a experience in higher education. Psicothema, 23, 274-281.

Oliveira, J. D., Oliveira, V., \& Souza, C. (2009). Estilos cognitivos: Uma pequisa com estudantes de contabilidade. Brazilian Business Review, 6, 82-103.

O’Connor, K. P., \& Blowers, G. H. (1980). Cognitive style, set and sorting strategy. Journal of Psychology, 71, 17-22.

Pennings, A. H. (1991). Altering the strategies in embeddedfigure and water-level tasks via instruction: A neo-piagetian learning study. Perceptual and Motor Skills, 72, 639-660.

Pierce, J. W. (1980). Field Independence and imagery-assisted prose recall of children. Journal of Educational Psychology, 72, 200-203.

Pintrich, P. R. (2002). The role of metacognitive knowledge in learning, teaching and assessing. Theory into practice, 41, 219-225.

Pintrich, P. R., \& De Groot, E. V. (1990). Motivational and self-regulated learning components of classroom academic performance. Journal of Educational Psychology, 82, 33-40.

Pintrich, P. R., Smith, D. A., García, T., \& McKeachie, W. J. (1991). A manual of the Motivated Strategies for Learning Questionnaire (MSLQ). Ann Arbor, MI: National Center for Research to Improve Postsecundary Teaching and Learning.

Pocinho, M. (2010). Psicologia, cognição e sucesso escolar: Concepção e validação dum programa de estratégias de aprendizagem. Psicologia: Reflexão e Crítica, 23, 362-373.

Pressley, M., \& Harris, K. R. (2006). Cognitive strategies instruction: From basic research to classrom instruction. In P. A. Alexander \& P. H. Winne (Eds.), Handbook of Educational Psychology (pp. 265-286). Mahwah, NJ: Lawrence Erlbaum.

Price, L. (2004). Individual differences in learning: Cognitive control, cognitive style, and learning style. Educational Psychology, 24, 681-698.

Rayner, S. Y., \& Riding, R. (1997). Towards a categorisation of cognitive styles and learning styles. Educational Psychology, 17, 5-27.

Rickards, J. P., Fajen, B. R., Sullivan, J. F., \& Gillespie, G. (1997). Signaling, notetaking, and field independencedependence in text comprehension and recall. Journal of Educational Psychology, 89, 508-517.

Riding, R. (1997). On the nature of cognitive style. Educational Psychology, 17, 29-49.

Rohde, T. E., \& Thompson, L. A. (2006). Predicting academic achievement with cognitive ability. Intelligence, 35, 83-92.

Rozencwajg, P. (1991). Analysis of problem solving strategies on the Kohs Block Design Test. European Journal of Psychology of Education, 6, 73-88.

Rush, G., \& Moore, D. (1991). Effects of restructuring training and cognitive style. Educational Psychology, 11, 309-321. 
Tinajero, C., Lemos, S. M., Araújo, M., Ferraces, M. J. \& Páramo, M. F. (2012). Cognitive Style and Learning Strategies as Factors which Affect Academic Achievement of Brazilian University Students.

Saracho, O. N. (2000). A framework for effective classroom teaching: Matching teachers' and students' cognitive styles. In R. J. Riding \& S. G. Rayner (Eds.), International perspectives on individual differences: Vol. 1. Cognitive styles (pp. 297-314). Stamford, CT: Ablex.

Schneider, W., Kron-Sperl, V., \& Hünnerkopf, M. (2007). The development of young children's memory strategies: Evidence from the Würzburg Longitudinal Memory Study. European Journal of Developmental Psychology, 6, 70-99.

Sobel, M. E. (1982). Asymptotic confidence intervals for indirect effects in structural equations models. In S. Leinhart (Ed.), Sociological methodology (pp. 290-313). San Francisco: Jossey-Bass.

Spiro, R. J., \& Tirre, C. (1980). Individual differences in schema utilization during discourse processing. Journal of Educational Psychology, 72, 204-208.

Stern, E. B., \& Hassanein, R. S. (1992). Efficacy and efficiency: Self-designed versus instructor-designed study tools. The American Journal of Occupational Therapy, 14, 253-266.

Sternberg, R. J., Grigorenko, E. L., \& Zahn, L. F. (2008). Styles of learning and thinking matter in instruction and assessment. Perspective on Psychology Science, 3, 486-506.

Sternberg, R. J., \& Williams, W. M. (2002). Educational Psychology. Boston: Allyn-Bacon.

Tinajero, C., \& Páramo, M. F. (1997). Field dependenceindependence and academic achievement: A reexamination of their relationship. British Journal of Educational Psychology, 67, 199-212.

Tinajero, C., \& Páramo, M. F. (1998). Field dependenceindependence and academic achievement: A review of research and theory. European Journal of Psychology of Education, 13, 227-251.

Tsakanikos, E. (2006). Associative learning and perceptual style: Are associated events perceived analytically or as a whole? Personality and Individual Differences, 40, 579-586.

Vermunt, J. D. (1996). Metacognitive, cognitive and affective aspects of learning styles and strategies: A phenomenographic analysis. Higher Education, 31, 25-50.

Vrugt, A., \& Oort, F. J. (2008). Metacognition, achievement goals, study strategies and academic achievement: Pathways to achievement. Metacognition Learning, 30, 123-146.

Weinstein, C. E. (1987). Learning and Study Strategies Inventory. Clearwater, FL: $\mathrm{H} \& \mathrm{H}$.

Weinstein, C. E., \& Mayer, R. E. (1986). The teaching on learning strategies. In M. C. Wittrock (Ed.), Handbook of research on teaching (pp. 315-327). New York: MacMillan.

Witkin, H. A., Oltman, P. K., Raskin, E., \& Karp, S. A. (1971). A manual for the embedded figures tests. Palo Alto, CA: Consulting Psychologists Press.

Zhang, L., \& Sternberg, R. J. (2005). A Threefold Model of Intellectual Styles. Educational Psychology Review, 17, $1-53$.

Zimmerman, B. J. (2002). Becoming a self-regulated learner: An overview. Theory Into Practice, 41, 64-70.

Zimmerman, B. J., \& Martinez-Pons, M. (1990). Student differences in self-regulated learning: Relating grade, sex, and giftedness to self-efficacy and strategy use. Journal of Educational Psychology, 82, 51-59. 